\title{
IN MEMORIAM: MIRKO JURAK (1935-2014)
}

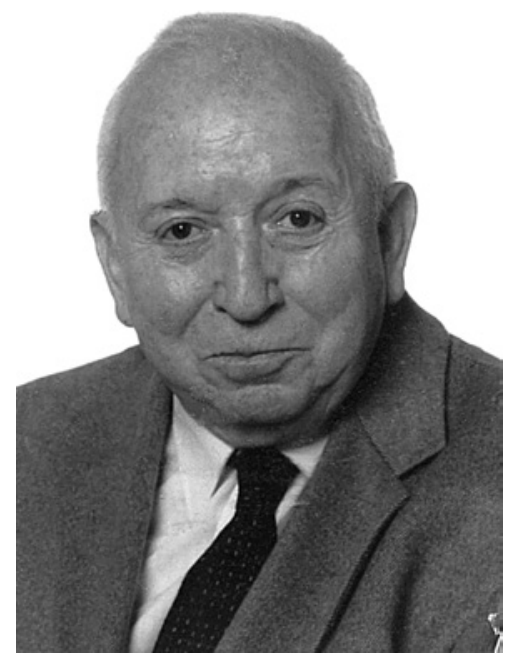

\section{BIOGRAPHY}

I.

Dr. Mirko Jurak graduated in English and Russian Literature from the University of Ljubljana's Faculty of Arts. In 1963 he departed for England to commence graduate studies at the University of Sussex, under the mentorship of the well-known literary historian David Daiches. In 1967 he received his doctorate for his work on English poetic political drama between 1930 and 1960. For the academic year 1970/71 he was a guest professor at Drake University in Iowa. He also held lectures at the University of Maribor.

Before his retirement in 2005, he was a full professor at the Faculty of Arts in Ljubljana, where he introduced courses in Shakespearean drama as well as in Australian and Canadian literature to the Department of English. Between 1979 and 1981 he was Associate Dean, and between 1981 and 1983 he was Dean of the Faculty of Arts. From 1984 to 1988 he headed the Department of Germanic Languages and Literatures, and from 1991 to 1993 he was Vice-Rector of the University of Ljubljana. He was co-founder and Vice President of the European Association for Australian Studies (EASA). Professor Jurak organized two high-profile international conferences in Bled: one on Australian Literature in 1982, and, in 1988, one on intercultural studies in the United States, Canada and Europe.

From 1990 to 1995 Professor Jurak was president of the Slovenian Emigrant Association, as well as the Vice President of the Republic of Slovenia's Office for Slovenians Abroad. For many years he was also a member of the boards for the "Drama" and "MGL" theatres in Ljubljana. Further, he was president of the Slovenian Association for Foreign Languages and Literatures and editor of their newsletter. He was involved in the journals on emigrant issues Rodna gruda, Slovenija and Dve domovini. In 2000 he became Editorin-chief of the Faculty of Arts' journal Acta neophilologica. He received the Faculty of Arts' Award of Merit in 1989, and the University of Ljubljana's Award of Merit in 1990.

Professor Jurak's main research and teaching areas were: Elizabethan drama (with a particular emphasis on Shakespeare), 20th-century English and American drama, and Slovenian emigrant literature in English. His bibliography consists over 300 entries, including the monograph Dileme parabolične umetnosti (1975), which is a discussion 
of the role and importance of sources for Shakespeare's plays. He also published the important first survey of Slovenian emigrant literature in Canada, as well as several forewords to Slovenian translations of English and American writers for the "100 novels" and "Nobel Laureates" series.

II.

Mirko was a long-time professor of English and American Literature and mentor to a great many Slovenian undergraduate and graduate students, but also to American, Australian, and Italian students, since he lectured abroad in addition to working at the University of Ljubljana. As a young man, he had wanted to become an actor, though for various reasons this was not to be. And so he dedicated his entire professional life to researching and teaching English and American drama, indeed to all English-language literature. His bibliography is extensive and wide-ranging, and he wrote a series of monographs and textbooks for students at the Universities of Ljubljana and Maribor.

In his illustrious academic career, he was Dean of the Faculty of Arts and ViceRector of the University of Ljubljana, as well as co-founder or executive member of such leading European associations for literature and culture as the European Association for Australian Studies and the European Association for American Studies. Mirko was also responsible for bringing leading thinkers to the Faculty of Arts, and to the Slovenian Academy of Sciences and Arts, among them, the Canadian literary critic Northrop Frye, the literary historian David Daiches, the British writer David Lodge, narratologist Karl Franz Stanzel, as well as many other literary critics - but also writers - from the Englishspeaking world. For me, however, Mirko was first and foremost my professor, my mentor for my Master's and $\mathrm{PhD}$ degrees, and a dear colleague at the department of literature.

We all learned a great deal from Mirko, and he was always trying to instil in students a love of English-language literature and for literature in general. Beyond Slovenia, he was very well-regarded as a scholar and, always and everywhere, he endeavoured to make known the fruits of Slovenian academia.

In 2000, after having been for many years executive editor of the Faculty of Arts' Acta neophilologica (founded by Professor Janez Stanonik), Mirko became the Editorin-chief of the scholarly journal. The journal published a series of studies of Slovenian emigration (as manifested in emigrant media and literature) written by Slovenian and foreign literary historians, many of whom were of Slovenian descent and living abroad. This research was pioneering for the areas of Slovenian emigrant literature, especially in the United States, Canada and Australia, a trio of lands for which Mirko had a particular affinity. I especially remember participating in the seminal 1988 international conference in Bled which focussed on intercultural literary studies in the United States, Canada and Europe and which was organized in conjunction with the Slovenian, American and Canadian embassies. Many attendees noted at the conference reception that they had never before, on a single occasion, shaken the hands of two ambassadors of large countries, namely, of the United States and Canada. Because this occurred just a few years before Slovenia became independent, this coming-together was by no means a given, and the Bled conference was thus of great political significance for the country. In addition, the 
conference was of pivotal importance for Slovenian intellectuals and professors of Slovenian descent who, for the most part from American and Canadian universities, lived in the diaspora and were previously mostly unpublished and little-known in Slovenian academia. The rest is history. Mirko clearly contributed significantly to knowledge and research of Slovenian emigrant literature, a field that has, increasingly, been included into the Slovenian literary canon.

Mirko was always innovative. In the 1980s he was the first to start teaching the postcolonial literatures of English-speaking countries, which in the European context was a novel undertaking; this tradition of thematic and critical decentralization and pluralisation of Anglo-American literary studies or literature in English continues at the Faculty of Arts' Department of English. For his efforts in propagating Australian literature and Australian studies in the European scholarly space, Mirko received an award from the Australian Government. As well, Mirko was the initiator of the interdisciplinary postgraduate (now doctoral) programme of American Studies at the Faculty of Arts. His decisive role in initiating and shaping the programme for English and German studies at the University of Maribor cannot be overlooked.

Mirko always looked at life from the sunny side and with optimism. Anyone who knew him knows that he was, in addition to being a conscientious and serious academic, also a bon vivant who loved company. This is the Mirko many of his colleagues from abroad knew - while appreciating his scholarly side, they also appreciated his purely human side. In addition to being a lover of the theatre, Mirko was a great lover of classical music, and for many years he was on the boards of Ljubljana's "Drama" and "MGL" theatres. As a theatre lover, he had very fond memories of his visits to London, and he wrote of London theatrical performances for Slovenian newspapers - in particular of his visit to Shakespeare's reconstructed Globe theatre. This roofless, semi-circular theatre, built as it was back in Shakespeare's time, seemed to Mirko to faithfully reflect the lively atmosphere and of the Elizabethan theatre of yore.

Right up until his last days Mirko continued to write about English drama, especially as it connected with and influenced Slovenian creativity for the stage. Over the past few years he published, in Acta neophilologica and in Slovenian newspapers, a number of extensive studies on Shakespeare and his influence on Slovenian playwrights - ranging from Anton Tomaž Linhart, Fran Levstik, Ivan Cankar, to Oton Župančič, Ivan Mrak, Bratko Kreft, and to contemporary Slovenian artists for the stage. With great dedication and as far as his health would allow it, he was also writing a book about these theatre links. The members of the editorial board of Acta neophilologica and generations of students of English will forever preserve beautiful and grateful memories of Mirko.

Let me conclude with a quote from Mirko's beloved Shakespeare and his play Hamlet, where Hamlet's friend Horatio accompanies Hamlet's demise with the following words:

Now cracks a noble heart. Good night sweet prince:

And flights of angels sing thee to thy rest!

(Hamlet, V.2) 
III.

\section{BIBLIOGRAPHY: Mirko Jurak}

\section{MONOGRAPHS}

Angleška poetično-politična drama v letih 1930-1940: Doctoral Dissertation. Ljubljana, [M. Jurak], 1967. 346 pp.

Glavna problemska območja v angleški poetično-politični dramatiki v letih 1930-1940 = The Main Spheres of the Problems in the English Politico-Poetic Drama (1930-1940): Abstract of the Doctoral Dissertation. Ljubljana, Univerza v Ljubljani, 1968. 40 pp.

English Poetry: An Anthology with a Critical and Historical Introduction for Foreign Students. Ljubljana, Državna založba Slovenije, 1972. 237 pp.

Dileme parabolične umetnosti: angleška angažirana poetična drama in gledališče. Ljubljana, Partizanska knjiga, 1975. 212 pp.

English Poetry: An Anthology with a Critical and Historical Introduction for Foreign Studens [!]. Second printing. Ljubljana, Državna založba Slovenije, 1980. 237 pp.

Notes on Shakespeare and His Contemporaries. Ljubljana, Filozofska fakulteta, Partizanska knjiga, 1980. 119 pp.

Od Shakespeara do naših sodobnikov: eseji in zapisi o angleški, ameriški in avstralski književnosti. Ljubljana, Znanstveni inštitut Filozofske fakultete, Partizanska knjiga, 1983. 175 pp.

Notes on Shakespeare and His Contemporaries. Ljubljana, Filozofska fakulteta, Partizanska knjiga, 1985. 119 pp.

English Poetry: An Anthology with a Critical and Historical Introduction for Foreign Students. Third printing. Ljubljana, Državna založba Slovenije, 1987. 237 pp.

Literarne in gledališke interpretacije in presoje. First printing. Ljubljana, Državna založba Slovenije, 1988. $151 \mathrm{pp}$.

Notes on Shakespeare and His Contemporaries. [Second printing]. Ljubljana, Filozofska fakulteta Univerze Edvarda Kardelja, Oddelek za germanske jezike in književnosti, 1989. 119 pp.

English Poetry: An Anthology with a Critical and Historical Introduction for Foreign Students. Fourth printing. Ljubljana, DZS, 1995. 237 pp.

Zapisi o Shakespearu = Notes on Shakespeare. Ljubljana, Znanstveni inštitut Filozofske fakultete, 1995. 171 pp. (Razprave Filozofske fakultete series)

Zapisi o Shakespearu $=$ Notes on Shakespeare . Revised ed. Ljubljana, Znanstveni inštitut Filozofske fakultete, 1997. 207 pp. (Razprave Filozofske fakultete series)

Angleška poezija in proza: izbrani eseji. Ljubljana, Znanstveni inštitut Filozofske fakultete, 2005. 227 pp. (Co-authored with Igor Maver). (Razprave Filozofske fakultete series) 


\section{STUDIES AND ARTICLES}

Joseph Conrad, Nostromo. Naši razgledi 8 (25 July 1959), no. 14 (181), pp. 341-342.

Antologija moderne jugoslovanske poezije v angleščini. Naši razgledi 9 (27 August 1960), no. 6 (207), p. 381.

Nekaj misli ob angleškem seminarju v Piranu. Naši razgledi 9 (27 September 1960), no. 18 (209), p. 417.

Jamesa Thurberja ni več. Naši razgledi 10 (27 December 1961), no. 24 (239), p. 563.

Novosti v angloameriški literaturi. Naši razgledi 10 (9 December 1961), no. 23 (238), pp. 446-547.

Uspel večer slovenske poezije v angleščini. Naši razgledi 10 (21 October 1961), no. 20 (235), p. 486.

E. E. Cummings: uveljavljeni eksperimenti v poeziji. Problemi 1 (1962/1963), no. 8, pp. 779-780.

Moderni tuji jeziki in zahteve našega časa. Naši razgledi 11 (23 June 1962), no. 12 (251), pp. 226-227.

Pesnik Robinson Jeffers. Naši razgledi 11 (7. apr. 1962), no. 7 (246), p. 138.

Srečanje s pisateljem Irvingom Stonom. Naši razgledi 11 (22 December 1962), no. 24 (263), p. 487.

Angleška in ameriška poezija na ekranu. Delo 5 (9 May 1963), no. 125, p. 5.

Iz angleških in ameriških revij. Naši razgledi 12 (23 February 1963), no. 4 (267), p. 83.

Koristna tradicija: seminar za anglistiko v Kopru. Delo 5 (13 August 1963), no. 220, p. 5.

“Pickwickovci” kot musical. Delo 5 (29 October 1963), no. 297, p. 5.

R. L. Frost: 1874-1963. Naši razgledi 12 (23 February 1963), no. 4 (267), p. 82.

Alojz Gradnik v angleščini. Delo 6 (15 July 1964), no. 191, p. 5.

Gledališče krutosti. Naši razgledi 13 (24 October 1964), no. 20 (307), p. 402.

Knjiga in študijska reforma. Naši razgledi 13 (21 March 1964), no. 6 (293), p. 105.

Nismo zadnji z Albeejem. Delo 6 (3 March 1964), no. 61, p. 6.

Nova angleška drama. Delo 6 (7 January 1964), no. 5, p. 5.

Ob 400-letnici Shakespearovega rojstva. Naši razgledi 13 (7 March 1964), no. 5 (292), p. 99.

Obisk v Shakespearovi domačiji. Delo 6 (15 May 1964), no. 131, p. 5.

Poetična drama na angleški televiziji. Delo 6 (16 April 1964), no. 105, p. 5.

Brighton - novo angleško univerzitetno mesto. Naši razgledi 13 (11 January 1965), no. 1 (288), p. 18.

Gost z Otoka: Stephen Spender. Delo 7 (16 May 1965), no. 129, p. 7.

Londonska kulturna panorama. Naši razgledi 14 (11 January 1965), no. 1 (288), p. 18.

English Poetical Verse Drama of the Thirties: Revision and Alteration. Acta Neophilologica 1 (1968), pp. 67-78.

Zapisi o književnem ustvarjanju W. H. Audena. Dialogi 4 (1968), pp. 395-405.

The Group Theatre: Its Development and Significance for the Modern English Theatre. Acta Neophilologica 2 (1969), pp. 3-43. 
Mesto in vloga junakov Saula Bellowa v sodobni družbi. Dialogi 5 (1969), pp. 267-276.

Nekateri problemi pri uvajanju interpretacij iz angleške književnosti. Vestnik DTJK 7 (1969), pp. 56-66.

Beat v ameriški književnosti. Prostor in čas 2 (1970), no. 4/5, pp. 265-267.

Gledališče krutosti. Prostor in čas 2 (1970), no. 2/3, pp. 163-172.

O nekaterih vprašanjih praktične stilistike in tehnike citiranja v angleščini. Vestnik DTJK 10 (1972), pp. 14-25.

Sta Marlowe in Shakespeare še naša sodobnika? Naši razgledi 21 (24 November 1972), no. 22 (501), pp. 613-614.

Dileme ob poeziji Ezre Pounda. Prostor in čas 5 (1973), pp. 107-110.

Dramaturgic Concepts of The English Group Theatre: The Totality of Artistic Involvement. Modern Drama 16 (1973), no. 1, pp. 81-86.

W. H. Auden: pesnik nemirnega časa. Prostor in čas 5 (1973), pp. 276-281.

Commitment and Character Portrayal in the British Politico-Poetic Drama of the 1930s. Educational Theatre Journal 26 (October 1974), no. 3, pp. 342-351. JSTOR. Web.

Louis MacNeice and Stephen Spender: Development and Alterations of Their Plays Written for the Group Theatre. Acta Neophilologica 7 (1974), pp. 59-65.

Šest oseb išče avtorja: pomen Pirandellovega ustvarjanja za sodobno dramatiko in gledališče. Prostor in čas 6 (1974), pp. 425-436.

American Poetry in Slovene Translations. In I. Koviloska-Poposka (ed.), Seminar on Contemporary American Poetry \& Criticism, October 11-15, 1977, Ohrid. Skopje, University "Kiril i Metodij”, Yugoslav-American Commission for Educational Exchanges, 1977, pp. 72-87.

Tokovi v razvoju avstralske književnosti. In: M. Jurak, Mavrična ptica: avstralske novele. Ljubljana, Mladinska knjiga, 1979, pp. 120-154. (Knjižnica Kondor, 180)

Slovenski srednješolci odlični v tujih jezikih. Delo 22 (21 February 1980), no. 43, p. 8.

Cultural Interrelation between Slovenia and America in Vatroslav Grill's Med dvema svetovoma (Between the Two Worlds). Acta Neophilologica 14 (1981), pp. 55-61.

The Relationship between Fictional and Non-fictional Elements in Adamic's Autobiographical Novels $=$ Razmerje med leposlovno in neleposlovno prozo $\mathrm{v}$ avtobiografskih romanih Louisa Adamiča. In J. Stanonik (ed.), Louis Adamič: simpozij, symposium, Ljubljana, 16.-18. September 1981. V Ljubljani, Univerza, [1981], pp. 125-136.

Slovene Immigrants in Mary Molek's Fictionalized Biography Immigrant Woman. Slovenski koledar 28 (1981), pp. 308-310.

Bogastvo različnosti: mednarodni simpozij o avstralski književnosti in kulturi, Bled, 21.-25. septembra 1982. Naši razgledi 31 (22 October 1982), no. 20 (739), pp. 601-602.

Janez Stanonik, šestdesetletnik. Delo 24 (5 January 1982), no. 2, p. 7.

Književnost v usmerjenem izobraževanju. Vestnik DTJK 16 (1982), no. 2, pp. 7-10.

Pesniško ustvarjanje slovenskih izseljencev. Delo 24 (14 October 1982), no. 240, p. 7. 
Prof. dr. Metod Mikuž: in memoriam. Naši razgledi 31 (23 April 1982), no. 8, p. 224.

Anton Grad: in memoriam. Delo 25 (5 April 1983), no. 79, p. 6.

David Herbert Lawrence. In M. Jurak, Od Shakespeara do naših sodobnikov: eseji in zapisi o angleški, ameriški in avstralski književnosti. Ljubljana, Znanstveni inštitut Filozofske fakultete, Partizanska knjiga, 1983, pp. 39-59.

E. E. Cummings. In M. Jurak, Od Shakespeara do naših sodobnikov: eseji in zapisi o angleški, ameriški in avstralski književnosti. Ljubljana, Znanstveni inštitut Filozofske fakultete, Partizanska knjiga, 1983, pp. 95-97.

Ernest Hemingway. In M. Jurak, Od Shakespeara do naših sodobnikov: eseji in zapisi o angleški, ameriški in avstralski književnosti. Ljubljana, Znanstveni inštitut Filozofske fakultete, Partizanska knjiga, 1983, pp. 31-38.

Ezra Pound. In M. Jurak, Od Shakespeara do naših sodobnikov: eseji in zapisi o angleški, ameriški in avstralski književnosti. Ljubljana, Znanstveni inštitut Filozofske fakultete, Partizanska knjiga, 1983, pp. 104-107.

George Bernard Shaw. In M. Jurak, Od Shakespeara do naših sodobnikov: eseji in zapisi o angleški, ameriški in avstralski književnosti. Ljubljana, Znanstveni inštitut Filozofske fakultete, Partizanska knjiga, 1983, pp. 70-78.

Jack Kerouac. In M. Jurak, Od Shakespeara do naših sodobnikov: eseji in zapisi o angleški, ameriški in avstralski književnosti. Ljubljana, Znanstveni inštitut Filozofske fakultete, Partizanska knjiga, 1983, pp. 101-104.

James Gould Cozzens: V oblasti ljubezni. In M. Jurak, Od Shakespeara do naših sodobnikov: eseji in zapisi o angleški, ameriški in avstralski književnosti. Ljubljana, Znanstveni inštitut Filozofske fakultete, Partizanska knjiga, 1983, pp. 94-95.

John Galsworhy: Zadnje poglavje. In M Jurak, Od Shakespeara do naših sodobnikov: eseji in zapisi o angleški, ameriški in avstralski književnosti. Ljubljana: Znanstveni inštitut Filozofske fakultete, Partizanska knjiga, 1983, pp. 99-100.

Joseph Conrad: Nostromo. In M. Jurak, Od Shakespeara do naših sodobnikov: eseji in zapisi o angleški, ameriški in avstralski književnosti. Ljubljana, Znanstveni inštitut Filozofske fakultete, Partizanska knjiga, 1983, pp. 92-94.

Kingsley Amis. In M. Jurak, Od Shakespeara do naših sodobnikov: eseji in zapisi o angleški, ameriški in avstralski književnosti. Ljubljana, Znanstveni inštitut Filozofske fakultete, Partizanska knjiga, 1983, pp. 11-16.

Muriel Spark: Memento mori. In M. Jurak, Od Shakespeara do naših sodobnikov: eseji in zapisi o angleški, ameriški in avstralski književnosti. Ljubljana, Znanstveni inštitut Filozofske fakultete, Partizanska knjiga, 1983, pp. 111-113.

Poetry Written by the Slovene Immigrants in Australia: Types of Imagery from the Old and the New Country. In M. Jurak (ed.), Australian Papers: Yugoslavia, Europe and Australia. V Ljubljani, Filozofska fakulteta, 1983, pp. 55-61. 
R. B. Sheridan in njegova komedija nravi. Gledališki list SNG, Drama 62 (October 1983), no. 3, pp. 52-53.

Robinson Jeffers. In M. Jurak, Od Shakespeara do naših sodobnikov: eseji in zapisi o angleški, ameriški in avstralski književnosti. Ljubljana, Znanstveni inštitut Filozofske fakultete, Partizanska knjiga, 1983, pp. 100-101.

Samuel Taylor Coleridge: Pesem starega mornarja. In M. Jurak, Od Shakespeara do naših sodobnikov: eseji in zapisi o angleški, ameriški in avstralski književnosti. Ljubljana, Znanstveni inštitut Filozofske fakultete, Partizanska knjiga, 1983, pp. 89-91.

Saul Bellow. In M. Jurak, Od Shakespeara do naših sodobnikov: eseji in zapisi o angleški, ameriški in avstralski književnosti. Ljubljana, Znanstveni inštitut Filozofske fakultete, Partizanska knjiga, 1983, pp. 17-23.

Sinclair Lewis. In M. Jurak, Od Shakespeara do naših sodobnikov: eseji in zapisi o angleški, ameriški in avstralski književnosti. Ljubljana, Znanstveni inštitut Filozofske fakultete, Partizanska knjiga, 1983, pp. 60-69.

Stephen Spender. In M. Jurak, Od Shakespeara do naših sodobnikov: eseji in zapisi o angleški, ameriški in avstralski književnosti. Ljubljana, Znanstveni inštitut Filozofske fakultete, Partizanska knjiga, 1983, pp. 113-115.

Svet svetlobe in teme. Naši razgledi 32 (9 December 1983), no. 23 (766), pp. 694-695.

William Faulkner. In M. Jurak, Od Shakespeara do naših sodobnikov: eseji in zapisi o angleški, ameriški in avstralski književnosti. Ljubljana, Znanstveni inštitut Filozofske fakultete, Partizanska knjiga, 1983, pp. 24-30.

Drama. In O. Hadžiselimović et al., Engleska književnost. Vol. 3. 1st ed. Sarajevo, Svjetlost, Beograd, Nolit, 1984, pp. 157-163. (Edicija Strane književnosti)

Dušan Ludvik, sedemdesetletnik. Delo 26 (14 December 1984), no. 290, p. 6.

Džordž Bernard Šo. In O. Hadžiselimović et al., Engleska književnost. Vol. 3. 1st ed. Sarajevo, Svjetlost, Beograd, Nolit, 1984, pp. 293-299. (Edicija Strane književnosti)

The Search for Cultural Identity in Ivan Kobal's Autobiographical Novel The Men who Built the Snowy. In D. Macdermott (ed.), Autobiographical \& Biographical Writing in the Commonwealth. Barcelona, Editorial AUSA, 1984, pp. 117-121.

The New World in Etbin Kristan's Plays. MELUS 12 (Winter 1985), no. 4, pp. 53-61.

“The New World” in Etbin Kristan's Plays. Slovenski koledar 32 (1985), pp. 228-232.

Tuji jeziki in stvarnost. In N. Bulatović (ed.), Posvetovanje Mesto in vloga tujih jezikov v naši družbi. Ljubljana, Društvo za tuje jezike in književnosti SRS, 1985, pp. 103-106.

Bogatstvo v različnosti: zbornik avstralskih Slovencev. Delo 28 (9 October 1986), no. 236, p. 5.

V iskanju identitete in - pri nas - zaslužene pozornosti: sodobna kanadska književnost. Delo 28 (25 December 1986), no. 299, p. 5. 
Mesto kanadskih studija na univerzitetu u Ljubljani. In V. Mirković and D. Vidak (eds.), Zbornik saopštenja o kanadskoj književnosti. Beograd, Odeljenje za informacije, kulturu i nauku Ambasade Kanade, 1987, pp. 59-65.

American, Canadian and European Scholars Meet at Lake Bled. Slovenija 2 (1988), no. 3, pp. 51-52.

Edgar L. Doctorow in sodobni ameriški roman. Delo 30 (20 October 1988), no. 189, p. 15.

An Interview with Stephen Spender. Acta Neophilologica 21 (1988), pp. 21-30.

Irony and Parody in Irish Drama: Possibilities of Translation. In B. Bramsback and M. Croghan (eds.), Anglo-Irish and Irish Literature: Aspects of Language and Culture: Proceedings of the Ninth International Congress of the International Association for the Study of Anglo-Irish Literature, held at Uppsala University, 4-7 August, 1986: Two Volumes. Uppsala, Academia Ubsaliensis, Stockholm, Almqvist \& Wiksell International (distributor), 1988, pp. 7-15. (Acta Universitatis Upsaliensis, Studia Anglistica Upsaliensia 64, 65)

Major Themes in Poetry Written by Slovene Immigrants in the United States of America and Canada. In M. Jurak (ed.), Cross-Cultural Studies: American, Canadian and European Literatures, 1945-1985: [Proceedings of the Symposium on Contemporary Literatures and Cultures of the United States of America and Canada, Bled, Yugoslavia, 9-14 May, 1988]. Ljubljana, Filozofska fakulteta, 1988, pp. 405-408.

Motivika v poeziji slovenskih izseljencev: kultura v ZDA in Kanadi (1945-1985). Delo 30 (5 May 1988), no. 103 , p. 7.

Slovenski pesniki v Avstraliji - razpeti med staro in novo domovino. Književna smotra 21 (1988), no. 69/72, pp. 69-71.

Major Themes in Poetry Written by Slovene Immigrants in the United States of America and Canada. Slovenski koledar 36 (1989), pp. 207-209.

Motivika v poeziji slovenskih izseljencev. Slovenski koledar 36 (1989), pp. 125-127.

Racionalizacija in preobrazba univerze. Naši razgledi 38 (23 June 1989), no. 12, pp. 352-354.

Thomas W. Shapcott in sodobna avstralska poezija: letošnji struški nagrajenec. Naši razgledi 38 (8 September 1989), no. 17, pp. 515-516.

Acta neophilologica, 1989. Delo 32 (4 January 1990), no. 2, p. 16.

Ivan Dolenc and John Krizanc: Two Canadian Authors of Slovene Origin. Dve domovini (1990), no. 1, pp. 301-307.

Ivan Dolenc and John Krizanc: Two Canadian Authors of Slovene Origin. In M. Dimić and D. Vidak (eds.), Književnost između dve domovine: III zbornik saopštenja članova i gostiju Društva. Beograd, Društvo za književnost i kulturu Jugoslavija-Kanada, 1990, pp. 19-22.

Literarni "trend": spoznati novo okolje in ohraniti svojo integriteto: slovenska izseljenska književnost v Kanadi. Delo 32 (18 January 1990), no. 14, p. 14.

"New Literatures" and English Studies: A Yugoslav Perspective. In W. Zach (ed.), Literature(s) in English: New Perspectives. Frankfurt am Main [etc.], Peter Lang, 1990, pp. 209-214. (Literature in English 1) 
Ivan Dolenc and John Krizanc: Two Canadian Authors of Slovene Origin. Slovenski koledar 38 $(1991<=1990>)$, pp. 201-203.

Pismo Slovencem po svetu. Rodna gruda 38 (1991), no. 2, p. 7.

Pismo Slovencem v svetu. Delo 33 (19 January 1991), no. 15, p. 31.

Izseljenci, domovina in Slovenska izseljenska matica. Slovenski koledar 39 (1992), pp. 25-28.

Jack Tomšič's Poetry: The Spiritual, Ethnic, Acculturational and Social Functions of Literature. Slovene Studies 14 (1992<issued 1994>), no. 2, pp. 139-148.

Janez Stanonik - sedemdesetletnik. Delo 33 (6 Januar 1992), no. 3, p. 2.

Janez Stanonik - Septagenarian. In M. Jurak (ed.), Literature, Culture and Ethnicity: Studies on Medieval, Renaissance and Modern Literatures: A Festschrift for Janez Stanonik. Ljubljana, Filozofska fakulteta, Znanstveni inštitut, 1992, pp. 9-17.

Prof. dr. Franc Lazarini: beseda ob grobu. Naši razgledi 41 (24 January 1992), no. 2, p. 38.

The Role of New Literatures in the Framework of English Studies. In M. Jurak (ed.), Literature, Culture and Ethnicity: Studies on Medieval, Renaissance and Modern Literatures: A Festschrift for Janez Stanonik. Ljubljana, Filozofska fakulteta, Znanstveni inštitut, 1992, pp. 45-49.

Teaching New Literatures at Ljubljana University. In W. Zach (ed.), English Literature and the University Curriculum. Frankfurt am Main [etc.], Peter Lang, 1992, pp. 144-146. (Literature in English 3)

Uspešno naprej po začrtani poti. Rodna gruda 39 (1992), no. 12, p. 5.

Vabilo rojakom za obisk. Rodna gruda 39 (1992), no. 5, p. 5.

Z oktetom Lesna med rojaki v ZDA in Kanadi. Rodna gruda 39 (1992), no. 10, p. 40-41.

The Dichotomy of Ana Praček-Krasna's Fiction. In J. Petrič (ed.), Slovenska beseda v angleškem kulturnem prostoru $=$ Slovene Word in the English Cultural Space . Ljubljana, Filozofska fakulteta, Odd. za germanske jezike in književnosti, Slovensko društvo za ameriške študije, cop. 1993, pp. 76-80.

Država in univerza naj bosta v partnerskem odnosu: avtonomija in odgovornost sodobne univerze. Delo 35 (2 June 1993), no. 125, p. 5.

Leto očiščenja in prerojenja. Slovenski izseljenski koledar 40 (1993), pp. 25-26.

Mladi in izseljenstvo: okrogla miza Slovenske izseljenske matice. Rodna gruda 40 (August/September 1993), no. 8/9, p. 13.

Novoletno pismo slovenskim izseljencem. Rodna gruda 40 (November/December 1993), no. 11/12, p. 5.

Professor Janez Stanonik: On His Seventieth Birthday. Slovenija 7 (1993), no. 1, p. 63.

Slovenska izseljenska matica vabi: [pismo]. Misli 42 (1993), no. 5, pp. 118-119, [and.], no. 8, p. 215.

Vrednostne premise. Teorija in praksa 30 (1993), no. 7/8, pp. 652-653.

Uspehi in težave na naši poti. Slovenski izseljenski koledar 41 (1994), p. 5-8. 
Vohunski roman kot odsev resničnosti nekdanje Jugoslavije: fikcija postane resničnost. Delo 36 (25 August 1994), no. 196, pp. 13-14.

Dorothy Auchterlonie (Green): The Global Feeling of Home. BELLS (1995), no. 6, pp. 89-94.

Fiction Turned into Reality: Andrew Moore's The Serbian Assignment. Acta Neophilologica 28 (1995), pp. 69-73.

Harold Pinter in sodobna angleška dramatika. Gledališki list, Prešernovo gledališče Kranj (1995/1996), no. 3, pp. 6-12.

Oddelek za germanske jezike in književnosti. In M. Orožen, Informativni kulturološki zbornik. V Ljubljani, Seminar slovenskega jezika, literature in kulture pri Oddelku za slovanske jezike in književnosti Filozofske fakultete, 1995, pp. 335-336.

Prisotnost angleške in ameriške književnosti v slovenski literaturi. In M. Orožen, Informativni kulturološki zbornik. V Ljubljani, Seminar slovenskega jezika, literature in kulture pri Oddelku za slovanske jezike in književnosti Filozofske fakultete, 1995, pp. 337-351.

Slovenci in Hrvaška = The Slovenes and Croatia. In V. Kržišnik-Bukić (ed.), Slovenci v Hrvaški: zbornik skupine avtorjev. Ljubljana, Inštitut za narodnostna vprašanja, 1995, pp. 13-16. (Projekt Slovenci v prostoru nekdanje Jugoslavije izven Slovenije 1)

Slovenska izseljenska matica - danes in v prihodnje. Slovenski izseljenski koledar 42 (1995), pp. 5-7.

The Teaching of English Literature. In N. Šabec (ed.) et al., Teaching English Language and Literature: zbornik referatov z mednarodnega posvetovanja anglistov $v$ Mariboru, 4.-5. marec 1994. Maribor, Pedagoška fakulteta, 1995, pp. 57-62.

Wystan Hugh Auden in medicina = Wystan Hugh Auden and Medicine. In Z. Zupanič Slavec (ed.), Med medicino in literaturo: ob 60-letnici predmeta Zgodovina medicine na MF v Ljubljani: [zbornik referatov]. Ljubljana, Inštitut za zgodovino medicine Medicinske fakultete, 1995, pp. [97]-113.

Slovene Poetry in Australia: From Terra Incognita to Terra Felix. Acta Neophilologica 29 (1996), pp. 59-67.

Slovene Travelogues about America, 1945-1995. In I. Maver (ed.), Ethnic Literature and Culture in the U.S.A., Canada, and Australia. Frankfurt am Main [etc.], Peter Lang, 1996, pp. 53-69.

Avstralsko-slovenski odnosi. In M. Javornik and A. Dermastja (eds.), Enciklopedija Slovenije. Reimpression. Ljubljana, Mladinska knjiga, 1997-, Vol. 1: A-Ca, pp. 136-138. (Co-authored with Zmago Šmitek, Božo Cerar).

From Terra Incognita to Terra Felix: Slovene Poetry in Australia. Slovenski izseljenski koledar 44 (1997), pp. 216-222.

Northrop Frye in Margaret Atwood: njun odnos do kanadske samobitnosti in kulture. In: J. Pogačnik (ed.), et al., Zbornik ob sedemdesetletnici Franceta Bernika. Ljubljana, Znanstvenoraziskovalni center SAZU, Inštitut za slovensko literaturo in literarne vede, 1997, pp. 227-240.

Cvetka Kocjančič. In J. Žitnik Serafin and H. Glušič (eds.), Slovenska izseljenska književnost. Ljubljana, ZRC, Rokus, 1999, Vol. 2: Severna Amerika, pp. 415-416. 
Irma Marinčič Ožbalt. In J. Žitnik Serafin and H. Glušič (eds.), Slovenska izseljenska književnost. Ljubljana, ZRC, Rokus, 1999, Vol. 2: Severna Amerika, pp. 422-423.

Ivan Dolenc. In J. Žitnik Serafin and H. Glušič (eds.), Slovenska izseljenska književnost. Ljubljana, ZRC, Rokus, 1999, Vol. 2: Severna Amerika, pp. 399-400.

Literarno ustvarjanje Slovencev v Kanadi. In J. Žitnik Serafin and H. Glušič (eds.), Slovenska izseljenska književnost. Ljubljana, ZRC, Rokus, 1999, Vol. 2: Severna Amerika, pp. 333-358, 363-383.

Louis Adamic and Vatro Grill: A Partnership of Equals? Acta Neophilologica 32 (1999), pp. 69-76.

Louis Adamic and Vatro Grill: A Partnership of Equals? In I. Gantar Godina (ed.), Intelektualci v diaspori: zbornik referatov simpozija "100. obletnica rojstva Louisa Adamiča - Intelektualci v diaspora”, Portorož, Slovenija, 1.-5. septembra 1998 = Intellectuals in Diaspora: Proceedings of the Symposium "100th Birth Anniversary of Louis Adamic - Intellectuals in Diaspora”, Portorož, Slovenia, 1.-5. September, 1998. Ljubljana, ZRC SAZU, Inštitut za slovensko izseljenstvo, 1999, pp. 13-20.

Mnenja o Shakespearu in o tragediji Romeo in Julija. In T. Logar (ed.), W. Shakespeare, William. Romeo in Julija. 1st ed. Ljubljana, DZS, 1999, pp. 168-169. (Zbirka Klasje)

Pomemben vzpon “novih književnosti” v angleščini. Delo 41 (13 May 1999), no. 108, p. 22.

Simbolika barv v prozi Stephena Crana. In J. Šumi (ed.), Raziskovanje kulturne ustvarjalnosti na Slovenskem: Šumijev zbornik: ob dvajsetletnici Znanstvenega inštituta. Ljubljana, Znanstveni inštitut Filozofske fakultete, 1999, pp. 147-153. (Razprave Filozofske fakultete series)

Ted (Božidar) Kramolc. In J. Žitnik Serafin and H. Glušič (eds.), Slovenska izseljenska književnost. Ljubljana, ZRC, Rokus, 1999, Vol. 2: Severna Amerika, pp. 416-418.

Tom Ložar. In J. Žitnik Serafin and H. Glušič (eds.), Slovenska izseljenska književnost. Ljubljana, ZRC, Rokus, 1999, Vol. 2: Severna Amerika, pp. 420-421.

Zdravko Jelinčič. In J. Žitnik Serafin and H. Glušič (eds.), Slovenska izseljenska književnost. Ljubljana, ZRC, Rokus, 1999, Vol. 2: Severna Amerika, pp. 408-409.

Dorothy Auchterlonie-Green: The Global Feeling of Home. In M. Jurak and I. Maver (eds.), Essays on Australian and Canadian Literature = Eseji o avstralski in kanadski književnosti. Ljubljana, Znanstveni inštitut Filozofske fakultete, 2000, pp. 57-61. (Razprave Filozofske fakultete series)

The English Romantic Movement and France Prešeren. In B. Paternu (ed.), Prešernovi dnevi v Kranju: simpozij ob 150-letnici smrti dr. Franceta Prešerna, od 2. do 5. februarja 1999 na Fakulteti za organizacijske vede v Kranju. Kranj, Mestna občina, 2000, pp. 239-259.

From Terra Incognita to Terra Felix: Slovene Poets in Australia. In M. Jurak and I. Maver (eds.), Essays on Australian and Canadian Literature = Eseji o avstralski in kanadski književnosti. Ljubljana, Znanstveni inštitut Filozofske fakultete, 2000, pp. 205-214. (Razprave Filozofske fakultete series)

Ivan Dolenc and John Krizanc: Two Canadian Authors of Slovene Origin. In M. Jurak and I. Maver (eds.), Essays on Australian and Canadian Literature = Eseji o avstralski in kanadski književnosti. Ljubljana, Znanstveni inštitut Filozofske fakultete, 2000, pp. 229-233. (Razprave Filozofske fakultete series) 
Ivan Kobal's Australian Experience. In M. Jurak and I. Maver (eds.), Essays on Australian and Canadian Literature $=$ Eseji o avstralski in kanadski književnosti. Ljubljana, Znanstveni inštitut Filozofske fakultete, 2000, pp. 223-228. (Razprave Filozofske fakultete series)

Northorp Frye and Margaret Atwood: On National Identity in Canadian Literature. In M. Jurak and I. Maver (eds.), Essays on Australian and Canadian literature $=$ Eseji o avstralski in kanadski književnosti. Ljubljana, Znanstveni inštitut Filozofske fakultete, 2000, pp. 121-130. (Razprave Filozofske fakultete series)

A Note on Slovene Immigrant Literature in Canada. In M. Jurak and I. Maver (eds.), Essays on Australian and Canadian Literature $=$ Eseji o avstralski in kanadski književnosti. Ljubljana, Znanstveni inštitut Filozofske fakultete, 2000, pp. 235-237. (Razprave Filozofske fakultete series)

Richard Flanagan's Novel on Slovene Immigrants in Australia. In M. Jurak and I. Maver (eds.), Essays on Australian and Canadian Literature = Eseji o avstralski in kanadski književnosti. Ljubljana, Znanstveni inštitut Filozofske fakultete, 2000, pp. 107-118. (Razprave Filozofske fakultete series)

Thirty-Two Years of Acta Neophilologica - with Gratitude to Its Founder and Editor Professor Janez Stanonik. Acta Neophilologica 33 (2000), no. 1/2, pp. 3-5.

Avanturisti kot dvomljivi vzorniki v romanih Ernesta Hemingwaya. In M. Jurak and J. Petrič (eds.), Ameriška proza: od realizma do postmodernizma. Ljubljana, Znanstveni inštitut Filozofske fakultete, 2001, pp. 73-82. (Razprave Filozofske fakultete series)

Družbenokulturno ustvarjanje slovenskih izseljencev v Kanadi. In M. Klemenčič and M. Trebše-Štolfa (eds.), Slovensko izseljenstvo: zbornik ob 50-letnici Slovenske izseljenske matice. Ljubljana, Združenje Slovenska izseljenska matica, 2001, pp. 193-209.

Klovnovski nasmeh junakov v zgodnjih delih Saula Bellowa. In M. Jurak and J. Petrič (eds.), Ameriška proza: od realizma do postmodernizma. Ljubljana, Znanstveni inštitut Filozofske fakultete, 2001, pp. 83-90. (Razprave Filozofske fakultete series)

'Novi svet' v dramah Etbina Kristana. In M. Jurak and J. Petrič (eds.), Ameriška proza: od realizma do postmodernizma. Ljubljana, Znanstveni inštitut Filozofske fakultete, 2001, pp. 169-174. (Razprave Filozofske fakultete series)

Simbolika barv v prozi Stephena Crana. In M. Jurak and J. Petrič (eds.), Ameriška proza: od realizma do postmodernizma. Ljubljana, Znanstveni inštitut Filozofske fakultete, 2001, pp. 15-21. (Razprave Filozofske fakultete series)

Sinclair Lewis - pisatelj kot družbeni kritik. In M. Jurak and J. Petrič (eds.), Ameriška proza: od realizma do postmodernizma. Ljubljana, Znanstveni inštitut Filozofske fakultete, 2001, pp. 33-44. (Razprave Filozofske fakultete series)

Slogovne ravni v romanu Louisa Adamiča Smeh v džungli. In M. Jurak and J. Petrič (eds.), Ameriška proza: od realizma do postmodernizma. Ljubljana, Znanstveni inštitut Filozofske fakultete, 2001, pp. 185-191. (Razprave Filozofske fakultete series)

Slovene Immigrants in Australia in Richard Flanagan's Novel The Sound of One Hand Clapping. Acta Neophilologica 34 (2001), no. 1/2, pp. 17-29. 
Svetovi fantastike, erotike in duhovnosti v romanih Vladimira Nabokova. In M. Jurak and J. Petrič (eds.), Ameriška proza: od realizma do postmodernizma. Ljubljana, Znanstveni inštitut Filozofske fakultete, 2001, pp. 61-71. (Razprave Filozofske fakultete series)

Tragika modernega človeka v romanu Williama Faulknerja Krik in bes. In M. Jurak and J. Petrič (eds.), Ameriška proza: od realizma do postmodernizma. Ljubljana, Znanstveni inštitut Filozofske fakultete, 2001, pp. 53-60. (Razprave Filozofske fakultete series)

William Faulkner: pripovedna tehnika kot izraz bivanjske problematike. In M. Jurak and J. Petrič (eds.), Ameriška proza: od realizma do postmodernizma. Ljubljana, Znanstveni inštitut Filozofske fakultete, 2001, pp. 45-52. (Razprave Filozofske fakultete series)

Akad. Janez Stanonik, 80-letnik. Delo 44 (28 January 2002), no. 22, p. 15.

Janez Stanonik - Octogenarian. Acta Neophilologica 35 (2002), no. 1/2, pp. 3.

Književno ustvarjanje slovenskih izseljencev v Kanadi in Avstraliji. In B. Krakar-Vogel (ed.), Ustvarjalnost Slovencev po svetu: zbornik predavanj. Ljubljana, Center za slovenščino kot drugi/tuji jezik pri Oddelku za slovanske jezike in književnosti Filozofske fakultete, 2002, pp. 73-89.

Ljubezen kot slepa strast in kot metafizika. Gledališki list SNG, Drama 82 (2002/2003), no. 11, pp. 15-18.

Northrop Frye and Margaret Atwood: On National Identity in Canadian Literature. In G. Stilz (ed.), Missions of Interdependence: A Literary Directory. Amsterdam, New York, Rodopi, 2002, pp. [23]-34. (ASNEL papers 6), (Cross/Cultures 58)

Ženski liki v Shakespearovih 'velikih tragedijah'. In K. Teržan-Kopecky (ed.), Dr. Mirko Križman, zaslužni profesor Univerze v Mariboru: 70 let: jubilejni zbornik. Maribor, Pedagoška fakulteta, 2003, pp. 198-217.

Neprecenljiv vir informacij: Katarina Bogataj Gradišnik - sedemdesetletnica. Delo 46 (3 March 2004), no. 52, pp. 8.

Angleška romantika in France Prešeren. In M. Jurak and I. Maver, Angleška poezija in proza: izbrani eseji. Ljubljana, Znanstveni inštitut Filozofske fakultete, 2005, pp. 81-94. (Razprave Filozofske fakultete series)

Charles P. Snow: volja do moči v romanu Hodniki oblasti. In M. Jurak and I. Maver, Angleška poezija in proza: izbrani eseji. Ljubljana, Znanstveni inštitut Filozofske fakultete, 2005, pp. 175-179. (Razprave Filozofske fakultete series)

E. M. Forster - večplastnost medkulturnih sporočil v romanu Potovanje v Indijo. In M. Jurak and I. Maver, Angleška poezija in proza: izbrani eseji. Ljubljana, Znanstveni inštitut Filozofske fakultete, 2005, pp. 167-174. (Razprave Filozofske fakultete series)

Kingsley Amis: portret “jeznega mladeniča” v romanu Srečni Jim. In M. Jurak and I. Maver, Angleška poezija in proza: izbrani eseji. Ljubljana, Znanstveni inštitut Filozofske fakultete, 2005, pp. 195-201. (Razprave Filozofske fakultete series)

Ob prvih Menartovih prevodih S. T. Coleridgea in lorda Byrona. In M. Jurak and I. Maver, Angleška poezija in proza: izbrani eseji. Ljubljana, Znanstveni inštitut Filozofske fakultete, 2005, pp. 75-80. (Razprave Filozofske fakultete series) 
Pogledi na razvoj angleške poezije. In M. Jurak and I. Maver, Angleška poezija in proza: izbrani eseji. Ljubljana, Znanstveni inštitut Filozofske fakultete, 2005, pp. 11-35. (Razprave Filozofske fakultete series)

Poti od samospoznanja do samouresničevanja v romanih Williama Goldinga. In M. Jurak and I. Maver, Angleška poezija in proza: izbrani eseji. Ljubljana, Znanstveni inštitut Filozofske fakultete, 2005, pp. 181-188. (Razprave Filozofske fakultete series)

Senzualnost in duhovnost v romanu D. H. Lawrencea Ljubimec lady Chatterley. In M. Jurak and I. Maver, Angleška poezija in proza: izbrani eseji. Ljubljana, Znanstveni inštitut Filozofske fakultete, 2005, pp. 133-156. (Razprave Filozofske fakultete series)

Shakespearovi soneti. In M. Jurak and I. Maver, Angleška poezija in proza: izbrani eseji. Ljubljana, Znanstveni inštitut Filozofske fakultete, 2005, pp. 61-74. (Razprave Filozofske fakultete series)

The Soul Divided: Slovene Immigrant Writers in Canada. In M. Kenneally (ed.) et al., From "English Literature" to "Literatures in English": International Perspectives: Festschrift in Honour of Wolfgang Zach. Heidelberg, Winter, 2005, pp. 195-212. (Anglistische Forschungen 347)

Tragični junaki v romanih Josepha Conrada: Nostromo, Z zahodnimi očmi. In M. Jurak and I. Maver, Angleška poezija in proza: izbrani eseji. Ljubljana, Znanstveni inštitut Filozofske fakultete, 2005, pp. 157-166. (Razprave Filozofske fakultete series).

Bernard Hickey: (1931-2007): In Memoriam. Acta Neophilologica 40 (2007), no. 1/2, pp. 207-209.

Jakob Kelemina on Shakespeare's Plays. Acta Neophilologica 40 (2007), no. 1/2, pp. 5-49.

Jakob Kelemina o Shakespearovi dramatiki. In Z. Kresnik (ed.), Dr. Jakob Kelemina: 1882-1957: ob petdesetletnici smrti. Ormož, Zgodovinsko društvo, 2008, pp. 39-56.

Ustanovitelj germanistike na ljubljanski univerzi (Jakob Kelemina). Delo 50 (14 May 2008), no. 110, p. 20.

William Shakespeare and Slovene Dramatists (I): A. T. Linhart's Miss Jenny Love. Acta Neophilologica 42 (2009), no. 1/2, pp. 3-34.

Kako se je Linhart učil pri Shakespearu: 230 let po nastanku prve slovenske "neprave" tragedije. Delo 52 (10 February 2010), no. 32, p. 18.

William Shakespeare and Slovene Dramatists (II): J. Jurčič, F. Levstik, I. Cankar, O. Župančič, B. Kreft: (The Makers of Myths). Acta Neophilologica 43 (2010), no. 1/2, pp. 3-48, 169-170.

William Shakespeare and Slovene Dramatists (III): (1930-2010). Acta Neophilologica 44 (2011), no. 1/2, pp. 3-34, 161-162.

Akademik prof. dr. Janez Stanonik, devetdesetletnik. Delo 54 (12 January 2012), no. 9, p. 16.

Janez Stanonik - Nonogenarian. Acta Neophilologica 45 (2012), no. 1/2, p. 4. 


\section{REVIEWS, PREFACES, FOREWORDS, INTRODUCTIONS}

E. Schmidt: Simon Bolivar. Naši razgledi 8 (12 December 1959), no. 23 (190), p. 552.

Galsworthyjev chef-d'ouvre v celoti v slovenščini: J. Galsworthy: Zadnje poglavje. CZ. Naši razgledi 9 (6 February 1960), no. 3 (194), p. 69.

Stric Tom v slovenskih prevodih: H. Beecher-Stowe: Koča strica Toma. Mladinska knjiga 1959. Naši razgledi 9 (5 March 1960), no. 5, p. 118.

Izdelana tradicija J. G. Cozzensa. Naši razgledi 11 (11 August 1962), no. 15 (254), pp. 296.

Ob Menartovem prevodu Coleridgeove pesnitve. Jezik in slovstvo 8 (December 1962), no. 3, pp. 89-91.

Folklorni elementi v romanu Moby Dick. Naši razgledi 12 (11 May 1963), no. 9 (272), p. 181.

Antologija Neka druga dežela. Delo 6 (14 June 1964), no. 161, p. 6.

Byron: Parizina: Menartova prepesnitev v bibliofilski zbirki “večni sopotniki”. Naši razgledi 13 (11 January 1964), no. 1 (288), p. 13.

Louis Adamič: Vrnitev v rodni kraj. Naši razgledi 13 (9 February 1964), no. 3 (266), p. 55.

Shakespearovi soneti v prevodu J. Menarta. Naši razgledi 14 (26 June 1965), no. 12 (323), p. 252.

Angažirana gledališka avantgarda: Terminal v izvedbi newyorškega The Open Theatra. Naši razgledi 20 (24 September 1971), no. 18 (473), pp. 546.

T. S. Eliot v teoriji in praksi poetične drame: ob uprizoritvi igre Umor v katedrali v celjskem slovenskem ljudskem gledališču. Naši razgledi 20 (22 October 1971), no. 20 (475), pp. 609-610.

Posebnosti sodobnega angleškega romana: [Muriel Spark: Memento mori]. Prostor in čas 5 (December 1973), no. 12, pp. 767-770.

Več skrbi gledališču. Prostor in čas 5 (December 1973), no. 12, pp. 778-779.

Vloga in pomen virov za Shakespearovo dramatiko. In W. Shakespeare, Venera in Adonis. Lukrecija. Tožba zaljubljene. Zaljubljeni romar. Pesmi za razne napeve. Feniks in grlica, (Zbrana dela). Ljubljana, Državna založba Slovenije, 1973, pp. 499-545.

Musical pred Shakespearom in Pinterjem: Londonski poletni gledališki utrip. Naši razgledi 24 (29 August 1974), no. 16 (567), p. 425.

Poti in iskanja sodobnega gledališča. Prostor in čas 6 (March/April 1974), [no.] 3/4, pp. 229-230.

Raznovrstno in živo: gledališki vtisi iz New Yorka. Naši razgledi 23 (26 July 1974), no. 14 (541), pp. 375-376.

Spremna beseda o avtorju: [Ernest Hemingway]. In E. Hemingway, Komu zvoni. V Ljubljani, Cankarjeva založba, 1975, pp. 593-611. (Nobelovci 17)

O iskanju harmonije v človeku in vesolju. In D. H. Lawrence, Ljubimec lady Chatterley. V Ljubljani, Cankarjeva založba, 1976, pp. 5-44. (Zbirka Sto romanov 80, 1; 80, 2)

Dobrodošlica s pridržki: The Prospect Theatre na mednarodnih poletnih igrah v Ljubljani: W. Shakespeare: Antonij in Kleopatra, Hamlet. Naši razgledi 26 (12 August 1977), no. 15 (614), p. 391. 
Spremna beseda o avtorju: [Saul Bellow]. In S. Bellow, Henderson, kralj dežja. V Ljubljani, Cankarjeva založba, 1977, pp. 361-377. (Nobelovci 37)

Spremna beseda o avtorju: [George Bernard Shaw]. In G. B. Shaw, Kandida. V Ljubljani, Cankarjeva založba, 1978, pp. 431-451. (Nobelovci 41)

Spremna beseda o avtorju: [Sinclair Lewis]. In S. Lewis, To se pri nas ne more zgoditi. V Ljubljani, Cankarjeva založba, 1978, pp. 389-411. (Nobelovci 46)

Vloga in pomen virov za Shakespearovo dramatiko. In W. Shakespeare, Zbrane gledališke igre. Ljubljana, Mladinska knjiga, 1978, pp. 140-184.

Zapis na robu berila iz angleške in ameriške književnosti. Vestnik DTJK 12 (1978), no. 1, pp. 1-16.

Je bil (ljubezni) trud zaman? Gledališki list Slovenskega ljudskega gledališča Celje, (1979/1980), no. 6, pp. 7-9.

Poezija Marka Strnada. Naši razgledi 28 (12 January 1979), no. 1 (648), p. 27.

Spremna beseda o avtorju. In W. Faulkner, Absalom, Absalom! V Ljubljani, Cankarjeva založba, 1979, pp. 379-395. (Nobelovci 55)

Mary Molek: Immigrant Woman. Published by M. Molek, Inc., Dover (Delaware), 1976. Acta Neophilologica 13 (1980), no. 1/2, pp. 84-86.

Uvodna beseda. In L. Adamič, Smeh v džungli. Ljubljana, Borec, 1983, pp. 13-19.

Spremna beseda. In W. Shakespeare, Romeo in Julija. Julij Cezar. Hamlet. Ljubljana, Mladinska knjiga, 1984, pp. 371-435. (Knjižnica Kondor 223)

Faulknerjev krik in bes. In W. Faulkner, Krik in bes. Ljubljana, Cankarjeva založba, 1985, pp. 329[341]. (Ameriški roman)

Lepota domišljije kot resnica o življenju v romanih Vladimira Nabokova. In V. Vladimirovič Nabokov, Ada ali strast. Ljubljana, Cankarjeva založba, 1985, pp. 525-[542]. (Ameriški roman)

Avstralski pisatelj o NOB in Jugoslaviji: Thomas Keneally: Season in Purgatory (Obdobje v vicah), Collins, London in Sydney, 1976. Naši razgledi 35 (26 September 1986), no. 18 (833), pp. 537-539.

Usoda moderne, "uspešne" ženske v igri Caryl Churchill Punce in pol. Gledališki list SNG, Drama 65 (May 1986), no. 9, pp. 118-121.

Zbornik avstralskih Slovencev. Svobodni razgovori 4 (1986), no. 4, p. 20.

C. P. Snow med tujci in brati v romanu Hodniki oblasti. In C. P. Snow, Hodniki oblasti. V Ljubljani, Cankarjeva založba, 1988, pp. 385-[391]. (Angleški roman).

E. M. Forster in odkrivanje neznanega v romanu Potovanje v Indijo. In E. M. Forster, Potovanje v Indijo. V Ljubljani, Cankarjeva založba, 1988, pp. 333-[343]. (Angleški roman)

O Lawrencovem Ljubimcu lady Chatterley. Gledališki list Šentjakobskega gledališča (1988/89), no. 4, pp. 4-5.

Novemu berilu na pot: [Literatures in English 1]. Prosvetni delavec 41 (5 February 1990), no. 2, pp. 8. 
Pesmi slovenskih izseljencev v Avstraliji: pomembna obogatitev slovenskega književnega ustvarjanja. In I. Cimerman (ed.), Lipa šumi med evkalipti: izbor pesmi Slovencev v Avstraliji. Ljubljana, Slovenska izseljenska matica, P. Amalietti, 1990, pp. 13-15.

O Romeu in Juliji. In W. Shakespeare, Romeo in Julija. Ljubljana, Mladinska knjiga, 1991, pp. 225233.

Z zahodnimi očmi. In J. Conrad, Z zahodnimi očmi. V Ljubljani, Cankarjeva založba, 1994, pp. 347[358]. (Zbirka XX. stoletje)

William Shakespeare: Sen kresne noči: le žlahtno razvedrilo ali kaj več? Gledališki list SNG, Opera in balet (1995/1996), no. 4, pp. [3-4].

Aktualnost Othellove tragike. In W. Shakespeare, Othello. Ljubljana, Mladinska knjiga, 1996, pp. 207-222.

Shakespearov Hamlet - nekdaj in danes. In W. Shakespeare, Hamlet. Ljubljana, Mladinska knjiga, 1996, pp. 241-266. (Klasiki Kondorja 17)

Matjaz Klemencic, ed., Etnicni fraternalizem v priseljenskih dezelaj[!deželah] - Ethnic Fraternalism in Immigrant Countries. (Maribor: Pedagoska fakulteta, 1996). 433 pp. American Studies in Europe (1997), no. 38, p. 23.

Slovenska izseljenska literatura v Kanadi in med ameriškimi Slovenci: ob izidu knjige Gospodar Golega ozemlja. Rast 8 (1997), no. 1/2, pp. 61-73. (Co-authored with Cvetka Kocjančič, Nada Šabec, and Franci Šali).

Pogledi na razvoj angleške poezije. In Antologija angleške poezije: od začetkov do konca 20. Stoletja. V Ljubljani, Cankarjeva založba, 1997, pp. 747-780. (Zbirka Bela krizantema).

Shakespearov Hamlet - nekdaj in danes. In W. Shakesepare, Hamlet. Ljubljana, Mladinska knjiga, 1997, pp. 241-266. (Klasiki Kondorja 17)

Usodna univerzalnost zla v Shakespearovem Macbethu. In W. Shakespeare, Macbeth. Ljubljana, Mladinska knjiga, 1997, pp. 153-171.

Kritika (ameriške) družbe. In S. Lewis, Glavna cesta. V Ljubljani, Cankarjeva založba, 1998, pp. 591[604]. (Zbirka XX. stoletje)

O celoti in posameznostih: še petkrat o Macbethu. Delo 40 (20 January 1998), no. 15, p. 17. (Coauthored with Aleš Jan, Francka Slivnik, Helena Šobar Zajc, France Vurnik).

Resničnost kresne noči in sanje vsakdanjosti? In W. Shakespeare, Sen kresne noči. Ljubljana, Mladinska knjiga, 1998, pp. 127-147.

Življenje in delo Williama Shakespeara. In W. Shakespeare, William Shakespeare. Bilingual ed. Ljubljana, Mladinska knjiga, 1998, pp. 147-151. (Zbirka Mojstri lirike)

Je sprava - v Shakespearovem Viharju - pravljica ali resničnost. In W. Shakespeare, Vihar. Ljubljana, Mladinska knjiga, 1999, pp. 135-161.

Uvod. In J. Žitnik Serafin and H. Glušič (eds.), Slovenska izseljenska književnost. Ljubljana, ZRC, Rokus, 1999, Vol. 2: Severna Amerika, pp. 307-331. 
Je ukročena trmoglavka že res ukročena?: spremna beseda. In W. Shakespeare, Ukročena trmoglavka. Ljubljana, Mladinska knjiga, 2001, pp. 149-167.

Knjigi na pot. In M. Kuzmič, Slovenski izseljenci iz Prekmurja v Bethlehemu v ZDA: 1893-1924: naselitev in njihove zgodovinske, socialne, politične, literarne in verske dejavnosti, Ljubljana, Založba ZRC, ZRC SAZU, 2001, pp. 9-10. (Co-authored with Matjaž Klemenčič). (Migracije 2).

Michael Ondaatje in njegovo mesto v multikulturni kanadski družbi. In M. Ondaatje, Zbrana dela Billyja the Kida: levoročne pesmi. Ljubljana, Sanje, 2002, pp. 129-136.

Veličastni Miltonov ep v sijajnem slovenskem prevodu Marjana Strojana: John Milton, Izgubljeni raj, Cankarjeva založba, Ljubljana 2004. Apokalipsa (2005), no. 87/88/89, pp. 175-178.

Večplastnost romanov ameriškega pisatelja Johna Steinbecka. In D. Čerče, Pripovedništvo Johna Steinbecka: družbenokritična misel v tradiciji mitov in legend. Maribor, Mariborska literarna družba, 2006, pp. 9-14. (Zbirka Absint 4)

\section{EDITOR}

Vestnik - Društvo za tuje jezike in književnosti. Ljubljana, Društvo za tuje jezike in književnosti R Slovenije, 1962-2006. (Editor 1962-1963, 1972).

Acta Neophilologica. Ljubljana, Filozofska fakulteta Univerze v Ljubljani, 1968-. (Member of editorial board 1968-1999, editor 2000-2014).

A Collection of Shorter English Poems. Ljubljana, Univerza, 1968. 196 pp.

Berila iz angleške in ameriške književnosti = Readings in English and American Literature. First printing. Ljubljana, Državna založba Slovenije, 1978. 531 pp.

Berila iz angleške in ameriške književnosti = Readings in English and American Literature. [Second printing]. Ljubljana, Državna založba Slovenije, 1980. 531 pp.

Australian Papers: Yugoslavia, Europe and Australia. V Ljubljani, Filozofska fakulteta, 1983. 321 pp.

Berila iz angleške in ameriške književnosti = Readings in English and American Literature. [Third printing]. Maribor, Obzorja, 1983. 531 pp.

Cross-Cultural Studies: American, Canadian and European Literatures, 1945-1985: [Proceedings of the Symposium on Contemporary Literatures and Cultures of the United States of America and Canada, Bled, Yugoslavia, 9-14 May, 1988]. Ljubljana, Filozofska fakulteta, 1988. 521 pp.

Literatures in English 1: [British, American and Other Authors Writing in English]. First printing. Maribor, Obzorja, 1990. 187 pp. (Srednje izobraževanje)

Literatures in English 2: A Practical Reader: [British, American and Other Authors Writing in English]. First printing. Maribor, Obzorja, 1990. 199 pp. (Srednje izobraževanje)

Literatures in English 1: A Practical Reader. Second printing. Maribor, Obzorja, 1991. 187 pp. (Srednje izobraževanje). 
Literature, Culture and Ethnicity: Studies on Medieval, Renaissance and Modern Literatures: A Festschrift for Janez Stanonik. Ljubljana, Filozofska fakulteta, Znanstveni inštitut, 1992. 332 pp.

Literatures in English 1: A Practical Reader: [British, American and Other Authors Writing in English]. Third printing. Maribor, Obzorja, 1994. 187 pp. (Srednje izobraževanje)

Literatures in English 2: A Practical Reader: [British, American and Other Authors Writing in English]. Second printing. Maribor, Obzorja, 1994. 199 pp. (Srednje izobraževanje)

Essays on Australian and Canadian Literature = Eseji o avstralski in kanadski književnosti. Ljubljana, Znanstveni inštitut Filozofske fakultete, 2000. 238 pp. (Co-edited with Igor Maver). (Razprave Filozofske fakultete series)

Ameriška proza: od realizma do postmodernizma. Ljubljana, Znanstveni inštitut Filozofske fakultete, 2001. 209 pp. (Co-edited with Jerneja Petrič). (Razprave Filozofske fakultete series).

\section{INTERVIEWS WITH AND ARTICLES ON MIRKO JURAK}

Mirko Jurak, asistent pri katedri za angleški jezik in književnost. In Biografije in bibliografije univerzitetnih učiteljev in sodelavcev, Vol. 2. Ljubljana, Univerza, 1969, p. 93.

Dr. lit. zg. znan. Mirko Jurak, dipl. fil., izr. prof. za angleško in ameriško književnost. In Biografije in bibliografije univerzitetnih učiteljev, znanstvenih delavcev in sodelavcev, (3 vols.), Vol. 1. Ljubljana, Univerza, 1979, pp. 65-66.

Jurak, Mirko, 11. 9. 1935, Ljubljana ; literarni zgodovinar, gledališki kritik. In Slovenska književnost. Ljubljana, Cankarjeva založba, 1982, pp. 132-133.

Kanadska in ameriška književnost organizirano stopata v naš svet: pogovor s profesorjem. Delo 29 (18 June 1987), no. 140, p. 3. [Interviewed by Janko Svetina]

Za zbliževanje izobrazbene ravni evropskih univerz: ob dveh znanstvenih poteh. Delo 31 (10 August 1989), no. 183, p. 5. [Interviewed by Janko Svetina]

"Ali je tudi na drugi strani taka poštenost?": Slovenska izseljenska matica: intervju s predsednikom Slovenske izseljenske matice prof. dr. Mirkom Jurakom in njenim tajnikom Janezom Rogljem. Slovenec 75 (11 July 1991), no. 14, p. 4. [Interviewed by Branka Sotošek ]

Angleška literatura manj naklonjena manjšim sestram: počitniški pogovor s predavateljem in piscem. Delo 37 (31 August 1995), no. 201, p. 11. [Interviewed by Jože Horvat) ]

Dr. lit. zg. znan. Mirko Jurak, dipl. fil., red. prof. za angleško in ameriško književnost. In Biografije in bibliografije univerzitetnih učiteljev, znanstvenih delavcev in sodelavcev, (4 vols.), Vol. 1, Ljubljana, Univerza, 1995, pp. 31-32.

Jurak, Mirko, 11. 9. 1935, Ljubljana ; literarni zgodovinar, gledališki kritik. In J. Kos, K. Dolinar, A. Blatnik (eds.), Slovenska književnost. Ljubljana, Cankarjeva založba, 1996, pp. 170-171.

Jurak, Mirko, 11. 9. 1935 v Ljubljani, literarni zgodovinar, anglist. In D. Bajt, Slovenski kdo je kdo. Ljubljana, Nova revija, 1999, p. 206. 
Dr. lit. zg. znan. Mirko Jurak, dipl. fil., red. prof. za angleško in ameriško književnost. In Biografije in bibliografije univerzitetnih učiteljev, znanstvenih delavcev in sodelavcev, (5 vols.), Vol. 3 , Ljubljana, Univerza, 1999, pp. 2223-2225.

Dr. Mirko Jurak (Ljubljana, 11. 9. 1935). In Zbornik (Filozofske fakultete): 1919-1990. Ljubljana, Filozofska fakulteta, 2000, pp 355-356.

Dr. Mirko Jurak (Ljubljana, 11. 9. 1935). In Enciklopedija Slovenije, Vol. 4, Ljubljana, Mladinska knjiga, 2001, p. 354.

Maver, Igor: Prof. dr. Mirko Jurak, sedemdesetletnik. Delo 47 (27 October 2005), no. 250, p. 19. (Coauthored with Jerneja Petrič). Reprinted in Ameriška domovina 107 (2005), no. 41, p. 15.

Jurak, Mirko (Ljubljana, 11. 9. 1935) literarni zgodovinar, kritik. In Osebnosti: veliki slovenski biografski leksikon (2 vols.), Vol. 1, Ljubljana, Mladinska knjiga, 2008, p. 427.

Maver, Igor: Mirko Jurak (1935-2014): nekrolog. Delo 56 (10 October 2014), no. 236, p. 21.

Bibliography prepared by Kristina Pegan-Vičič 